\title{
EERSTEJAARSTUDENTE EN DIE P.U. VIR C.H.O.
}

\section{Inleiding}

Na die Tweede Wêreldoorlog het daar in Suid-Afrika en feitlik alle ander lande 'n buitengewone toestroming van studente na universiteite en kolleges plaasgevind. Ná die V.S.A. is die toegangspersentasie van studente na ons Suid-Afrikaanse universiteite inderdaad die hoogste in die wêreld. Twee ondersoeke wat onafhanklik van mekaar in die R.S.A. uitgevoer is, het aangetoon dat oor ' $n$ periode van 10 jaar meer as $80 \%$ van dié wat matrikuleer as universiteitstudente geregistreer word. In 1955 het dr. A. L. Kotzé, die huidige Direkteur van Onderwys in Transvaal, bekend gemaak dat $78 \%$ van dié leerlinge wat aan die einde van 1954 gematrikuleer het, tot inrigtings vir Hoër Onderwys toegetree het.

\section{Druiping}

Gedagtig aan ons klein blanke en groot nie-blanke bevolking, ons fenomenale groei op nywerheidsgebied en ons beperkte blanke mannekrag - veral hoog geskoolde, skeppende mannekrag - openbaar bogenoemde 'n tendens waarin ons ons maar net kan verheug. Hierteenoor egter wek die hoë druip- en afvalsyfer van universiteitstudente groot kommer. Die Steyn-statistiese ondersoek het byvoorbeeld aan die lig gebring dat slegs $\mathbf{5 5} \%$ van die beginnende voltydse studente aan ons universiteite 'n eerste graad verwerf in die minimum tydperk vir 'n graad plus twee jaar. Dit is verder bekend dat minder as $50 \%$ 'n graad behaal in die minimum voorgeskrewe periode van drie jaar.

Hierdie mislukkings, studente wat hulle kursusse staak of die universiteit verlaat voor hulle ' $n$ graad behaal, is nie net vir studente en ouers 'n groot teleurstelling, frustrasie en finansiële verlies nie, maar is ook 'n verkwisting van belowende mensemateriaal en geld vir ons volk en staat.

Die leerling wat matriek in die A-baan geslaag het, het voldoen aan die skolastiese eise wat deur die universiteit via die Gemeenskaplike Matrikulasieraad gestel word. Maar hoe kom dit dan, is die logiese vraag, dat so baie studente, veral eerstejaarstudente, aan ons universiteite druip en uitsak? 


\section{Verklaring}

Die verklaring wat in die verlede die meeste aandag geniet het, was dat hierdie mislukkings aan 'n gebrek aan intellektuele vermoëns toegeskryf moet word. Hierdie gedagte het tot gevolg gehad dat ons universiteite aan hoër toelatingsvereistes begin het. Maar die ervaring, ook aan oorsese universiteite wat selfs toetse gestandaardiseer het om die vermoëns en aanleg van voornemende studente te bepaal, het gou geleer dat verstandelike vermoëns alleen maar 'n teleurstellende waarborg is vir akademiese sukses.

Daar is ' $n$ hoër positiewe korrelasie tussen intelligensie en prestasie in die matriekeksamen as wat daar is tussen intelligensie en akademiese prestasie op universiteitsvlak. Laasgenoemde korrelasie is inderdaad besonder laag en soos verwag kan word het ondersoeke aangetoon dat die matriekresultate 'n veel hoër voorspellingswaarde het vir universiteitsukses as blote intelligensie.

Hierdie bevindinge het sielkundiges en opvoedkundiges op die gedagte gebring dat die skolastiese en intellektuele toerusting van die matrikulant nie alleen verantwoordelik is vir die mislukkings nie, maar dat ander persoonlikheidsfaktore soos motivering, emosionele stabiliteit, etiese, morele en godsdienstige waardes en maatskaplike omstandighede 'n veel groter rol speel as wat aanvanklik vermoed is. Dit is nie onmoontlik dat hierdie faktore, waarsonder ook pligsbesef, volharding, ywer, werklus, werkkrag en selfdissipline ressorteer, selfs 'n beter voorspellingsindeks mag inhou as die blote intelligensie nie. Dit behoort dus nie verbasing te wek dat bowendien gevind is dat meer as 'n kwart van die studente wat met 'n gemiddelde van minder as $50 \%$ in matriek geslaag het, dit regkry om op universiteit hulle prestasie te verbeter. Op die prestasieverhoging af, vorder hulle inderdaad beter as die studente wat in die matriekeindeksamen 'n gemiddelde van $60 \%$ en hoër bereik het.

\section{Gekompliseerde probleem}

Dit moet vir die leser duidelik wees dat ons hier nie met 'n simplistiese probleem te doen het nie. En vir 'n gekompliseerde probleem is daar nie, soos anvanklik aangevoer is, ' $n$ simplistiese verklaring en oplossing nie.

Hierdie probleem, veral dié van die eerstejaarstudent waar 
die mislukkings op sy hoogste is, moet op die volle breedte van die universiteitslewe, op alle fasette en met inskakeling van alle instansies, aangepak word. Soos dit in ons tyd maar ooral die geval is, val die klem in ons universiteite ook al te veel op die objektiewe dinge en op realiteite en te min op die subjektiewe en op idealiteite: te veel op intellektuele vermoëns en aanleg, kennisontginning, kennisbemagtiging, reproduksie van kennis, metodebeoefening en metodemaking op formele objektiewe onderrig dus en te min op die dieper subjektiewe dimensies van opvoeding en vorming.

Dat baie eerstejaarstudente, deur die matriekeindeksamen vir die universiteite geselekteer, aan ons universiteite hulle onseker en selfs verlore voel, kan nie betwyfel word nie. Vergeleke met die middelbare skool is die universiteit, veral teenswoordig, nie alleen veel groter in omvang en baie meer kompleks in die struktuur van sy formele en informele samestelling en organisasie nie, maar as inrigting vir hoër onderwys én opvoeding handhaaf die universiteit ook nie dieselfde peil van opvoedkundige beheer oor sy studente as wat aan die middelbare skool, ten aansien van sy leerlinge, die geval is nie.

\section{Opknapping}

Hiermee word nie bedoel - en ek oriënteer my nou spesifiek tot die houding van die P.U. vir C.H.O. - dat die universiteit onverskillig staan teenoor die behoeftes en probleme van sy studente nie. Terselfdertyd handhaaf die P.U. ook nie 'n houding of beleid van vertroeteling, of oorheersing, wat die student sy vryheid en verantwoordelikheid ontneem en sy groei na selfstandigheid en volwassenheid in die weg staar nie. En eerder as om die middelbare skool die sondebok te makk vir die mislukkings, stel die P.U. hom op die standpunt dat dit hier om die opknapping van sy eie huishouding gaan.

'n Volledige uiteensetting van die "waar" en die ,hoe" van sodanige opknapping aan die P.U., word nie hier beoog nie, maar die aandag word graag op aspekte gevestig wat ons in hierdie verband as van besondere betekenis beskou.

$\mathrm{Na}$ jarelange aanvoorwerk en proefneming het die P.U. aan die begin van 1966 formeel daartoe oorgegaan om 'n Instituut vir Sielkundige en Opvoedkundige Dienste en Navorsing in die lewe te roep. Hierdie Instituut is nie aan 'n spesifieke studiedepartement gekoppel nie, maar funksioneer interdepartemen- 
teel. As sodanig trag die Instituut om dosente van besondere departemente, soos onder meer die Sielkunde, Opvoedkunde, Maatskaplike Werk, Interfakultêre Wysbegeerte ('n lewensbeskoulike vormingsvak wat vir alle studente verpligtend is) te betrek om hulp, voorligting en selfs sielkundige terapie te bied aan dié studente wat daaraan 'n behoefte het.

Om so 'n omvattende diens te kan lewer, werk die Instituut vanselfsprekend saam met die Administrasie, die Dept. van Ontwikkeling, die Biblioteek, die Studenteraad, die dekane, hoofde van departemente, individuele dosente van studente, koshuisvaders, voogdosente (wat oor groepe eerstejaarstudente aangewys is), ouers, vriende, predikante en geneeshere van studente.

Hieruit word dit duidelik dat die Instituut, met die oog op sy studentediens, alle fasette, instansies en persone betrek wat kan help. Slegs deur sodanige integrasie en samesnoering van kragte, glo ons, kan 'n volledige en daarmee ook doelmatige diens aan die studente, veral eerstejaarstudente, van die P.U. gelewer word. En al gaan dit primêr om die studente, kan inmiddels net opgemerk word, dat die Instituut ook 'n voorligtings- en terapeutiese diens aan die gemeenskap lewer wat allersyds verwelkom word.

In die byna vier jaar van die Instituut se bestaan, het dit duidelik geword dat die studente, veral weer eerstejaarstudente, ruimskoots gebruik maak van die dienste wat aangebied word. Ons statistiek toon aan dat die aantal studente wat om hulp kom aanklop inderdaad van jaar tot jaar toeneem. Op die praktyk van die dienste af gaan dit hoofsaaklik om kursus-, studie-, beroepskeuse, lewensbeskoulike, interpersoonlike en individuele persoonlikheidsprobleme. Enigsins anders benader, kan ons dit so stel dat die studente se probleme veral rondom die volgende konfliksituasies lê: sukses teenoor mislukking, afhanklikheid teenoor onafhanklikheid en die seksualiteit en die godsdiens onderskeidelik.

Hieruit kry ons 'n goeie aanduiding van die belangrike rol wat subjektiewe persoonlikheidsfaktore in die lewe van die student speel en van die behoefte wat daar by ons adolessente en jong mense bestaan om voorgelig en gelei te word. Die konfliksituasie is implisiet en eksplisiet deel van die jeug en miskien ook nodig vir die jeug in hul groei na volwassenheid. Daarom hunker die jeug, wat wil leef en hom wil uitdruk, na leierskap in die groot ideë en geestelike waardes van ons kul- 
tuur - na 'n beskouende analise van die diepere lewensfeite en die binding en veiligheid van 'n gegronde lewens- en wêreldbeskouing.

Maar die Instituut spits hom in sy dienste nie net op die individuele student toe nie. Met die oog op die aanvanklike oriëntering en (spoedige) inskakeling van die eerstejaarstudent in die volle spektrum van die universiteitslewe, beplan 'n ver. teenwoordigende ad hoc-kommissie van die Raad van Beheer wat oor die Instituut gestel is, die hele oriënteringsprogram vir die eerstejaarstudente wat aan die begin van die akademiese jaar aangebied word. Dit is 'n breë program waarin die eerste. jaarstudent ingelig en voorgelig word oor die administratiewe en akademiese masjinerie van die universiteit, die verenigingslewe en die sport - al die fasette en komponente van die universiteitsrealiteit wat vir die student van belang is. Spesifieke voorligting oor die gebruik van die biblioteek en die aanwending van studietegnieke ontvang besondere beklemtoning en die studente wat daaraan 'n behoefte het, word gedurende die oriënteringsperiode psigometries getoets en individueel voorgelig met die oog op kursus-, vak-, en uiteindelik beroepskeuse.

$\mathrm{Na}$ hierdie formele oriënteringsprogram sit die Studenteraad, die Huiskomitees, senior studente wat as voogde oor 'n aantal eerstejaars aangestel is en ander studenteliggame die inskakelingsproses voort. Ook in die klasse van die eerste week gaan die dosente oriënterend ten aansien van hulle onderskeie vakgebiede te werk en word die eerstejaars geleidelik in hulle akademiese bedrywighede betrek. Aansluitend kan ons ook net melding maak van die sogenaamde „tutorial system” wat deur sommige van die P.U. se studiedepartemente toegepas word en wat vir die studente besondere didaktiese waarde het, veral as die groot eerstejaarsklasse in gedagte gehou word. Die oriëntering en geleidelike inskakeling op akademiese vlak is besonder belangrik, omdat verskeie studente in die begin verward raak, agter raak, moed verloor en meermale nooit hierdie aanvanklike agterstand inhaal nie.

Van besondere belang is verder die rol wat die voogdosente, waarna reeds verwys is, aan die P.U. vir C.H.O. speel. Hierdie stelsel is al goed op die proef gestel en die hele organisasie daarvan is toegewys aan 'n ervare personeellid, 'n opvoedkundige, wat as hoofvoogdosent optree. Vroeg in die oriënteringsprogram ontmoet elke voogdosent sy groep eerstejaars, meermale tesame met hulle ouers. Hierna vind verdere ont- 
moetings plaas en die voogdosente gee praktiese raad aan hul studente oor al die vraelyste wat voltooi moet word, hoe die rooster gelees moet word, vestig die aandag op belangrike vereistes in die jaarboek, verduidelik die oriënteringsprogram, gesels oor klasprosedures, die keuse van kursusse en vakke, troos die wat verlore voel, en so meer. Alhoewel die ontmoetings met eerstejaarstudente geleidelik verminder, bly die voogdosente steeds in aanraking met diegene wat besondere hulp nodig het.

Ook die Dept. Ontwikkeling, waarvan vroeër melding gemaak is, skakel by die oriënteringsprogram in deur die ouers van eerstejaarstudente op georganiseerde wyse met dekane van Fakulteite, hoofde van Departemente en individuele dosente in aanraking te bring. Hier word belangrike bindingswerk gedoen deur die student en ouers gesamentlik met die universiteit en sy personeel kennis te laat maak. Op hierdie „ouerdag" gaan dit insgelyks in die koshuise druk toe: Studente en ouers ontmoet die koshuisvaders en geniet saam met hul kinders middagete in die onderskeie koshuise. Ook vir die predikante van die verskillende kerke word ruim geleentheid gebied om studente en ouers te ontmoet en te woord te staan.

\section{Navorsing}

Maar hiermee, so het die P.U. oor sy verantwoordelikheid as inrigting vir Christelike Hoër Onderwys besin, is die opdrag en taak van die universiteit ten aansien van sy studente nog nie voltooi nie - eintlik word 'n universiteit se taak nooit voltooi nie! 'n Breë, langtermyn navorsingsprojek word tans beoog oor die psigologie van die (huidige) universiteitstudent en die taak en aard van die (huidige) universiteitsdosent. Hierdie navorsingswerk sal eerstens gemunt moet word op 'n wetenskaplike beskouing van die Christelike karakter, die lewens- en wêreldbeskouing wat deur die P.U. gehuldig en gehandhaaf word; en op die basis hiervan sal die Universiteit se hele didaktiese opset onder die wetenskaplike vergrootglas geplaas word. Inderdaad 'n reuse taak, maar 'n taak wat ons opnuut stimuleer en ' $n$ taak wat onvermydelik weer sy stempel op die P.U. vir C.H.O. sal afdruk.

P.U. vir C.H.O.

T. A. van Dyk. 


\section{ERRATA (Koers, Junie 1969; Jaargang XXXVI, Nr. 6)}

Bl. 456, reël 2 van onder, lees kultuurtake i.p.v. kultuursake.

Bl. 457, reël 11 van onder, voeg ons in voor nie.

Bl. 459, reël 8 van onder, lees toevallige i.p.v. toevalligge.

Bl. 460 , reël 17 , lees beoefening i.p.v. boeefening.

Bl. 461 , reël 3 , voeg tussen kritiek en ontduik die volgende woorde in: ook op ons toepas. Ons mag hulle kritiek op ons nie.

Bl. 461, reël 13, skrap maar gryp.

Bl. 461, reël 14, skrap die hele lyn.

Bl. 461 , reël 14 van onder, lees oorsprongsroep i.p.v. oorsprongsgroep.

Bl. 461, reël 6 van onder, lees elan i.p.v. eland.

Bl. 462, reël 6 van onder, lees onontkombaar i.p.v. ontkombaar.

Bl. 462 , reël 13 van onder, voeg in aan na gaan.

Bl. 464, reël 14 van onder, lees onontkombaar i.p.v. ontkombaar.

Bl. 467, reël 1, lees dosente i.p.v. dosent.

Bl. 467, reël 6 van onder, voeg in ook na maar.

Bl. 468, reël 9, lees sin nog nie in sig i.p.v. sin, nog nie insig.

Bl. 472, reël 17 van onder, lees perspektivies i.p.v. perspektiveer.

Bl. 476, reël 10 van onder, lees dien i.p.v. doen.

Bl. 476, reël 8 van onder, lees onbewuste i.p.v. bewuste.

\section{BIBLIOTEKE AANDAG ASSEBLIEF}

By die uitgawes van April 1969 en Junie 1969 moet die jaargang wees: Jaargang XXXVI.

Die inhoudsopgawe agter in die uitgawe van Junie 1969 is dié van Jaargang XXXVI. 